\section{日本臨床外科学会山梨県支部抄録 (第79回山梨県臨床外科医学会)}

\author{
会 期: 平成30年 6 月 2 日（土） \\ $14: 00 \sim 15: 40$ \\ 会場：山梨大学医学部基礎研究棟 6 階大会 \\ 議室
}

当番世話人：市立甲府病院 外科 巾 芳昭

\begin{abstract}
1 残胃癌に対する腹腔鏡補助下残胃全摘術の経験
山梨大学医学部第一外科

○高橋和徳, 赤池英憲, 白石謙介, 河口賀彦, 清水浩紀, 古屋信 二, 細村直弘, 雨宮秀武, 川井田博充, 須藤 誠, 井上慎吾, 河 野 宽, 市川大輔
\end{abstract}

79歳、男性。55年前に胃潰瘍で幽門側胃切除、Billroth- II 法再建 の既往がある。紹介医に高血圧、高尿酸血症にて通院中、血液検 查で貧血を指摘された。当院へ精查目的で紹介され、上部消化管 内視鏡検查の結果、残胃空腸吻合部から空腸にかけて 1 型腫痬を 認めた。CT検查の結果、明らかなリンパ節転移や遠隔転移を認 めず、手術適応と判断した。手術は腹腔鏡下に開始した。臍下部 より直視下にポート挿入し腹腔内観察。癒着は軽度であり、拳上 空腸、吻合部の同定も容易であった。まず小腸間膜の動静脈を SMA 根部近傍で切離し輸入脚、輸出脚とも胃空腸吻合部から約 $10 \mathrm{~cm}$ で切離した。残胃全摘、D 2 - \#10郭清を腹腔鏡下にて完遂 し再建に移った。腸間膜のねじれのないことを確認し、左上腹部 の小切開創より空腸を体外に挙上し、まずY吻合を体外で行っ た。続いて経ロアンビル (OrVilTM) を用いて体胿内で食道空 腸吻合を行った。しかし、最後に吻合部の確認を行ったところ、 挙上空腸が㸚じれて吻合されていることが判明し、開腹移行、再 吻合を施行した。近年、胃癌に対する腹䏶鏡手術は、幽門部癌に 限らず、噴門部癌や残胃癌へと応用されている。しかし、より高 度な手技や視野展開が必要であることを踏まえつつ、手術を行う ことが重要だと考えられた。

\section{2 診断に難啮した巨大食道GIST の一例}

山梨大学医学部第二外科 ${ }^{1}$, 山梨大学第一外科 ${ }^{2}$

○野崎祐香里 ${ }^{1}$, 松原寛知 ${ }^{1}$, 椙村 彩 ${ }^{1}$, 内田 嚴 ${ }^{1}$, 松岡弘泰 ${ }^{1}$, 市原智史 ${ }^{1}$, 河口賀彦 ${ }^{2}$, 中島博之 ${ }^{1}$

症例は60歳代女性、右背部痛を主訴に近医を受診した。胸部CT 検査では、後縦隔を中心に $9 \times 8 \mathrm{~cm}$ の境界明瞭の腫瘤を認めた。 そのため縦隔腫瘍の疑いで手術目的に当科紹介となった。PET/ CTでは腫瘍に集積を認め、上部内視鏡検査ではEUSで食道の筋 層外に腫瘤を認めたため、神経原性腫瘍を最も疑い手術する方針 とした。手術は第 6 肋間で開胸し、術中に針生検を行ったが、迅 速病理診断では紡錘形の細胞主体で神経原性腫瘍またはGISTの 可能性があるという結果であった。腫瘍自体は食道と一部接して いたが、切除可能であったため、筋層を一部合併切除して摘出し た。最終的な病理組織所見では、紡錘形細胞が高密度に増殖して いて、免疫染色でCD34 (+)、c-kit (+)、S100 (-) であること から GIST と診断された。核分裂像はあまり目立たないが大きさ から高リスク群であり、術後補助療法として、イマチニブの内服 を外来にて行なっている。
3 メッケル捼室による絞扼性イレウスの 2 例 市立甲府病院外科

○樫本健太郎, 千須和寿直, 塚原 勇, 柴 修吾, 國友和善, 角 田 元, 宮澤正久, 飯野 弥, 巾 芳昭

症例 1 は20歳代、男性。2 日前からの右下腹部痛を主訴に当院へ 救急搬送された。腹部造影 CT で右骨盤内に短いclosed loopを疑 う所見があり、絞扼性イレウスの診断で緊急手術を施行した。下 腹部正中で開腹すると、回腸にメッケル喤室を認め、茎部分が捻 じれて壊死していた。壞死したメッケル悡室の根部を自動縫合器 で切除した。症例 2 は80歳代、男性。前日からの腹痛、嘔吐を主 訴に当院を受診。腹部造影 CT で複数の closed loopがあり、絞把 性イレウスと診断で緊急手術を施行した。中腹部正中切開で開腹 すると、多量の血性腹水とメッケル憩室を認めた。メッケル憩室 先端から索状物が伸びて腸間膜へ癒着し、絞抳性イレウスの原因 となっていた。壊死は回腸末端に及んでおり壊死した小腸を $70 \mathrm{~cm}$ 切除し、小腸と盲腸を自動縫合器で端側吻合した。今回、 メッケル㮩室が原因と思われる絞扼性イレウスを 2 例経験したの で、報告する。

4 多量下血をきたした小児メッケル憩室の一例 山梨大学医学部第二外科

○蓮田憲夫, 沼野史典, 中島博之

患児は 7 歳、男児。特記すべき既往疾患はなかった。下痢ととも に血便をきたす様になり、近医で感染性腸炎の診断で内服治療を 受けていた。翌日には腹痛と血便を繰り返す様になり、Hb 6.5 $\mathrm{g} / \mathrm{dl}$ の貧血のため赤血球濃厚液の輸血を要した。CTで、壁が肥 厚し盲端となった菅脘構造物を指摘され当科へ紹介された。 ${ }^{99 \mathrm{~m}} \mathrm{Tc}$ - pertechnetate シンチで集積を認めメッケル馝室の出血 と診断し緊急でメッケル稇室切除術を施行した。手術は臍部にポ

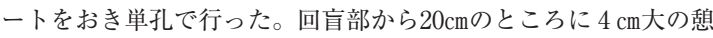
室を認め、臍部創から引き出して直視下に㰾室切除を行った。切 除標本で炎症所見は軽度で、異所性胃粘膜を認めた。術後経過は 良好で術後 7 日目に退院した。

5 山梨県におけるTAVI治療の現状

山梨大学医学部第二外科

○加賀重亜喜, 中島博之, 白岩 聡, 本田義博, 暮仁 猛, 榊原 賢士

当院は、平成 25 年10月に保険収載された大動脈弁狭窄症 (AS) に対する経カテーテル大動脈弁植え込み術（TAVI）が平成29年 7 月 3 日に実施施設として認定された。平成29年10月11日に第一 例目を実施して以来、これまでに13症例に施行した。山梨県の TAVIの現状をASに対する外科的大動脈弁置換術の手術成績と 併せて報告する。

6 外傷性直腸穿孔の一例

山梨大学医学部第一外科

○古谷元宏, 須藤 誠, 清水浩紀, 古屋信二, 中田祐紀, 河口賀 彦, 白石謙介, 細村直弘, 雨宮秀武, 川井田博充, 井上慎吾, 河 野 寛, 市川大輔

今回我々はガラス片による外傷性直腸穿孔を経験したので文献的 考察を加えて報告する。症例は62代の女性。23時頃、浴室で転倒 し臂部をガラス戸に打ちつけ受傷し、翌日の11時頃前医を受診し た。外傷性直腸穿孔の診断で手術目的に当院第一外科に転院搬送 となった。臂部〜仙骨部の左右方向に $12 \mathrm{~cm}$ 長の裂創、左慜部に 
$2.5 \mathrm{~cm}, 3.5 \mathrm{~cm}$ の裂創あり。臂部〜仙骨部の裂創は尾骨を触れら れる深さであった。裂創から異物は確認できず。骨盤部造影 CT で、直腸内、外旋筋、臂筋、仙骨孔内等に最大で長径 $5 \mathrm{~cm}$ 程度 の複数の異物遺残を認めた。

ガラス片による直腸穿孔と診断し、緊急手術を施行した。まず砕 石位で開腹による直腸切除、異物除去、止血、S 状結腸人工肛門 造設を行い、その後腹臥位にて篮部の創からの異物除去と洗浄、 創縫合を行った。直腸後腔剥離時に仙骨前面静脈叢からの出血を 認めた。また、仙骨孔内の異物は腹側からのアプローチでは除去 困難であった。整形外科にコンサルトしたが、背側からのアプロ 一チも困難であり、神経支配的には異物を残しても膀胱直腸障害 や下肢の麻痺などの後遺症が残る可能性は少ないとのことで、仙 骨孔の異物除去は行わない事とした。術後、臂部〜仙骨部の裂創 に創部感染見られたが経過は概ね順調で、排尿障害や下肢麻痺な どの大きな合併症なく経過している。

この症例では仙骨孔に異物が遺残したままであり、仙骨全面にも 細かい物が遺残していることを術後のCTで確認している。今後、 遺残物による臓器、神経損傷などに注意しフォローしていく必要 がある。

7

を施行した 1 例

直腸癌術後側方リンパ節再発に対し腹胿鏡下側方郭清

山梨厚生病院外科

○白典秀, 佐藤大輔, 宮原和弘, 山寺陽一

症例：70代女性。糖尿病性腎症で血液透析中。肛門縁から $2 \mathrm{~cm}$ を下端とする直腸癌 $(\mathrm{Rb}-\mathrm{P})$ に対し腹腔鏡下直腸切断術、 $\mathrm{prxD}$ 2 郭清施行。病理組織学的所見は、pT 2 N 1 M 0 pStage III aであ った。術後補助化学療法 (UFT/UZEL) 施行し経過観察中、術 後 4 年 9 ケ月目の CT 検查で、左側方リンパ節転移を認めた。そ の他に再発病変を認めず、左側方リンパ節転移単独再発に対し腹 腔鏡下左側方リンパ節郭清、左内腸骨動静脈合併切除術を施行。 手術時間 272 分、出血量 $50 \mathrm{~g}$ 、術後第13病日に退院となった。直 腸癌術後の側方リンパ節再発に対する腹腔鏡下側方リンパ節郭清 は安全に施行可能で、有用であると考える。

8 CT ガイド下膿瘍ドレナージ後に腹腔鏡下低位前方切 除術を行った直腸憩室穿通の 1 例

市立甲府病院外科

○須和寿直, 塚原 勇, 樫本健太郎, 柴 修吾, 角田 元, 國 友和善, 宮澤正久, 飯野 弥, 巾 芳昭

直腸㮩室は注腸造影で $0.1 \%$ 未満、結腸憩室症の $2.4 \%$ 以下の割合 で存在する稀な病態であり、時に炎症・狭窄・瘦孔などをおこす。 今回、直腸㮩室穿通による骨盤内膿瘍にCTガイド下ドレナージ 術・人工肛門造設術、その後、腹腔鏡下低位前方切除術を行った 症例を経験したので報告する。症例は70歳男性で、左内䅡動脈狭 窄症の治療で入院中であった。術後、食欲不振・発熱・炎症反応 の増悪があり、CTで多発する左側結腸䡯室と骨盤内膿瘍と診断 した。保存治療では改善せず、11病日に左䌓部からCTガイド下 膿瘍ドレナージを施行し、造影で直腸への瘦孔を疑った。28病日 に人工肛門造設術、69病日にドレーンの抜去、その 4 ヶ月後に腹 腔鏡下低位前方切除術を行った。術中所見では腹膜反転部の㓔痕 部で直腸が一塊化し、摘出標本では腹膜反転部の高さに媳室があ った。術後経過は良好で術後11日目に退院となり、人工肛門は後 日閉鎖する方針とした。 